\title{
Shrunken Life: Discourses of the Cryptic and the Miniature in Madagascar
}

\author{
Genese Marie Sodikoff
}

(D) https://orcid.org/0000-0003-0896-1140

Rutgers University-Newark, USA

\begin{abstract}
As scientists scour remnant habitats and "unmask" cryptic species with DNA barcoding, a boom of species discovery has enchanted the world. In Madagascar, recent discoveries of previously unknown miniature frogs, chameleons, and lemurs often photographed on human fingers or cradled in hands, have captured the public imagination. In this imagery of scale, the giant finger conveys the outsized impact of humanity on Earth, or points to what Susan Stewart (1996, p. 74) calls "a physical world of disorder and disproportion." Although the phenomenon of insular gigantism and dwarfism has shaped scientific discourses of evolution and extinction since the nineteenth century, recent reportage on "new" miniature and cryptic species reflects a sensibility beyond wistful nostalgia for creatures past. Species miniaturism evolves out of habitat loss, and living minifauna encapsulate the contraction of existential time, all the more pronounced by the effects of climate change. Photographs of cryptic minifauna therefore compel us to reflect on the whole of our losses, while they fuel the impulse to restock the "library of life" at micro-scale.
\end{abstract}

Keywords: extinction, cryptic species, miniature species, climate change, island rule, DNA barcoding, Madagascar

eTropic: electronic journal of studies in the tropics publishes new research from arts, humanities, social sciences and allied fields on the variety and interrelatedness of nature, culture, and society in the tropics. Published by James Cook University, a leading research institution on critical issues facing the world's Tropics. Free open access, Scopus Listed, Scimago Q1. Indexed in: Google Scholar, DOAJ, Crossref, Ulrich's, SHERPA/RoMEO, Pandora. ISSN 1448-2940. Creative Commons CC BY 4.0 free to download, save and reproduce. To cite, include: Author(s), Title of Paper, Editors (Eds.) Special Issue Title (Special Issue) eTropic, volume, issue, year, pages and DOI: http://dx.doi.org/10.25120/etropic.20.2.2021.3820 
eTropic 20.2 (2021) Special Issue: Tropical Imaginaries and Climate Crisis

A gainst the grain of mass extinction, recent species discoveries in Madagascar have caused excitement in scientific communities. The novel species include frogs, chameleons, and lemurs and are extraordinary for their tiny sizes. Photographs circulating online via digital and social media of minifauna perched on the tips of fingers or cradled in hands instill a sense of wonder, while they also put into relief the impact of humankind on the planet. The recent discoveries are not entirely the result of exploratory missions; they have also relied on advancements in genetic and scanning technologies. As new instruments illuminate structural differences in bodies that had previously been invisible to the human eye, scientists have been able to distinguish specimens once lumped together as singular species.

These two interlinked phenomena, the discovery of miniature species out there in the world and the parsing of cryptic minifauna in the laboratory, have yielded the discovery boom. The sense of wonder and excitement evoked by the images of novel miniature life - whether discovered in leaf litter or through DNA barcoding - is tempered by awareness of anthropogenic climate change and ecological degradation. This article explores how imagery of "cute" minifauna in popular science articles enters contemporary extinction discourse, attending to the ways miniature and gigantic lives have shaped perceptions of historical time, human ecological agency, and moral responsibility in European imaginations. I argue that the contrastive scale - tiny animal on human hand - taps into a European cultural lexicon of miniatures and giants. Moreover, images of minifauna symbolize a downward slide, a relentless downscaling of "Earth's library of life" (Greenfield, 2020). In other words, recent species discoveries suggest that finding novel megafauna within Earth's degraded habitats is now virtually impossible, and what remains are the miniature and microscopic lives that have eluded the scientific gaze thus far. In addition, to replenish the library of life, scientists increasingly rely on technologies more powerful than microscopes to draw increasingly fine taxonomic distinctions.

At first glance, the quest to find novel species in a context of mass extinction and global warming resembles the impulse of White museum curators of the nineteenth century, whose desire to collect indigenous people's material culture arose amidst the rapid demise of indigenous worlds. Cultural extinction was dictated by the colonial theory of social evolutionism - deemed a predictable result of the superior "fitness" of Whites and capitalism (Brantlinger, 2003). The extinction of wildlife species was also something to be mourned, and zoological artefacts of extinct or nearly extinct species became increasingly precious commodities. 
eTropic 20.2 (2021) Special Issue: Tropical Imaginaries and Climate Crisis

In the twenty-first century, the net impacts of modernization have not only created a void of endemic species around the globe, but the effects of deforestation and carbon emissions on the atmosphere are cascading into the future, no matter the types of mitigation we implement today. Climate change is imbricated with species extinction. While human-induced habitat destruction outpaces the effects of climate change on insular species, global warming amplifies the problem - for instance, drought and severe weather events transform habitats, which cause the movement of species populations, which in turn disrupts ecosystems in a constant feedback loop.

Climate change is projected to reduce the carbon stock of tropical forests. Scientists forecast that by 2080 an average forest carbon stock loss of 17\% in Madagascar will result from climate change. That is, beyond the loss of carbon stocks due to anthropogenic activity in forests, rising $\mathrm{CO}_{2}$ concentrations and changes in temperature and precipitation will impact the physiological response of vegetation, resulting in a shrinkage in the size of trees and shifts in the distribution of tree species (Vieilledent et al., 2016). The shrinkage of tree size results in a loss of biomass, further reducing the capacity of forests to store carbon, and again reflecting an ecological downward spiral.

The majority of climate change extinctions will occur in the tropics, where biodiversity and endemism are highest (Raxworthy et al., 2008). Rising temperatures are already exceeding the physiological tolerance of certain species. Changes in temperature and precipitation will continue to cause a reduction of species' ranges, and it will push species into new ranges, thereby impacting interactions amongst species (Cahill et al., 2012, p. 3). Some species populations may thrive in the new assemblages, but others will be outcompeted. In Madagascar, warming is causing the upslope displacement of reptiles and amphibians, a trend that affects tropical montane species in particular (Raxworthy et al., 2008). With regard to the endemic lemurs - found only on this one island - climate variability leaves them vulnerable to the disruption of neuroendrocrine processes, including, for example, reproductive cycles and lactation (Dunham et al., 2011; Wright, 2006). Scientists project increases in the mean temperature on the island of $1.1-2.6^{\circ} \mathrm{C}$. Greatest warming is predicted to occur in the drought-prone south, while moderate warming along the coast and in the north, the sites of remnant rain forests, makes them vulnerable to drying (Hannah et al., 2008; Tadross et al., 2008).

Amidst the immensity of these climatic and ecological threats, the event of species discovery is rare and precious enough, but revelations of new miniature species seem almost miraculous. Due to their "aesthetic charisma" (Lorimer, 2015, p. 46), their 
eTropic 20.2 (2021) Special Issue: Tropical Imaginaries and Climate Crisis

association with childhood and folklore, and their emergence within a context of accelerating loss and run-away climate change, the novel minifauna depicted in digital images urge the imagination to retreat into bioabundant worlds. Advancements in science and technology that assist in decoding minifauna suggest the possibility of ecological redemption through the discovery of new lives hiding in the ones we thought we knew.

To explore why visual representations of miniature species (particularly vertebrate ones) fascinate us, I draw inspiration from Susan Stewart's book On Longing: Narratives of the Miniature, the Gigantic, the Souvenir, the Collection (1996). In the Western tradition, she explains, representations of miniatures and giants work as metaphors that mediate human experiences of the world and contribute to formations of self and spacetime. She interprets the affective responses to figures of exaggerated size - whether Lilliputian or Brobdingnagian - as they are depicted in narrative, figurative art, and culture more broadly. I suggest that Westerners have also vested real-life dwarf and giant species with synecdochic significance. Imagery of disproportionate creatures invokes a history of human intrusion into other species' worlds and speaks of a process of anthropogenic transformation of the planet, particularly diminishment.

The process of downscaling the terrain of species discovery harks back to an earlier age of discovery enabled by the popularization of the microscope. Laura Forsberg explains that the widespread use of microscopes by amateur naturalists in the Victorian period "revealed real, living particles in the crevices of nature" and turned many Europeans into natural history enthusiasts (Forsberg, 2015, p. 640). The microscope offered access to invisibilia, a "scientific fairyland." Its influence on the Victorian imagination was reflected in the shrinkage of folkloric representations of fairies, transforming them from two- or three-foot tall beings into microscopic miniatures (Forsberg, 2015, p. 642). Technologies of invisibilia have become more refined, revealing lives lurking in the crevices of DNA.

What is important here is that this imagery of scale simultaneously conveys how humans situate themselves as species in the world. Visual (as well as written) representations of marvelous minifauna indicate an entire environment that lies outside the photo's frame (or the border of the written text). As we view images of whole, miniature animals juxtaposed against human appendages, we glean the context of planetary damage. While the presence of the human finger or hand implicates humanity in the dangerous state of environmental affairs, the tiny creatures offer seeds of hope amidst the ruination. 
eTropic 20.2 (2021) Special Issue: Tropical Imaginaries and Climate Crisis

In what follows, I take Stewart's insights to the ecological realm to trace accounts of European quests to find disproportionate species in Madagascar. The island has long attracted foreign explorers thanks to its unique biogeography, containing numerous exemplars of insular dwarfism and gigantism. These phenomena have inspired fictional narrative and scientific studies in the last few centuries. Historical texts and folklore indicate that Malagasy people have also been intrigued by the concept of miniaturization.

Since the seventeenth century, natural histories of Madagascar reveal that many of the island's fabled species have eluded discovery, consequently whetting the desire to ferret out concrete evidence of their existence. Species of exaggerated scale have, moreover, contributed to the representation of Madagascar as a "world out of time", in the dual sense of the anachronistic attributes of its wildlife, and its imminent ecological collapse (e.g. Lanting, 1990).

\section{Representations of the Island Rule}

Madagascar has long been a fertile ground for contemplating extinction events due to its high degree of species endemism and endangerment. Islands in general have served the advancement of science by revealing the mechanisms of evolution at smaller scale and, therefore, at a quicker pace. Islands are microcosms of humanecosystem interactions, illuminating "the sequence of human discovery, landscape modification, and biotic adjustment (or collapse)" (Burney, 1997, p. 438).

Madagascar's biogeography offers a classic example of the "island rule" formulated by J. Bristol Foster in 1963. The concept refers to the unique evolutionary pressures exerted on insular plants and animals. These pressures in Madagascar were enhanced by the oscillation of dryer and wetter periods during the Pleistocene, affecting the dispersion of flora and fauna (Mercier \& Wilmé, 2013). The limited terrain and restrictive ecological niches on islands in general result in remarkable growth: small plants take the form of trees, birds and insects lose the ability to fly, and many mainland species evolve as dwarf or giant versions (Lomolino, 2005, p. 1684; Foster, 1964; Carlquist,1974). As a curator of reptiles writes of Madagascar's chameleons: "So bizarre is the appearance of some of them that one might imagine they have developed as evolutionary jokes, beyond all bounds of utility and reasonable variation" (Barnett, 1937, p. 470).

Although scientific study of the island rule only took off in the 1960s, the phenomenon appears to have intrigued European writers as early as the eighteenth century. A 
classic literary allusion to the island rule occurs in Jonathan Swift's satire, Gulliver's Travels. Published in 1726, the story recounts the adventures of Lemuel Gulliver, whose ship is blown off course north of Madagascar and wrecked on the island of Lilliput, somewhere in the Indian Ocean (see Figure 1 below). Lilliput is inhabited by tiny people. Later in the story, Gulliver alights on the peninsula of Brobdingnag, populated by giants (Transforming the World, n.d.; Swift, 1920 [original 1726]).

Figure 1. Map showing the fictional island of Lilliput relative to Sumatra

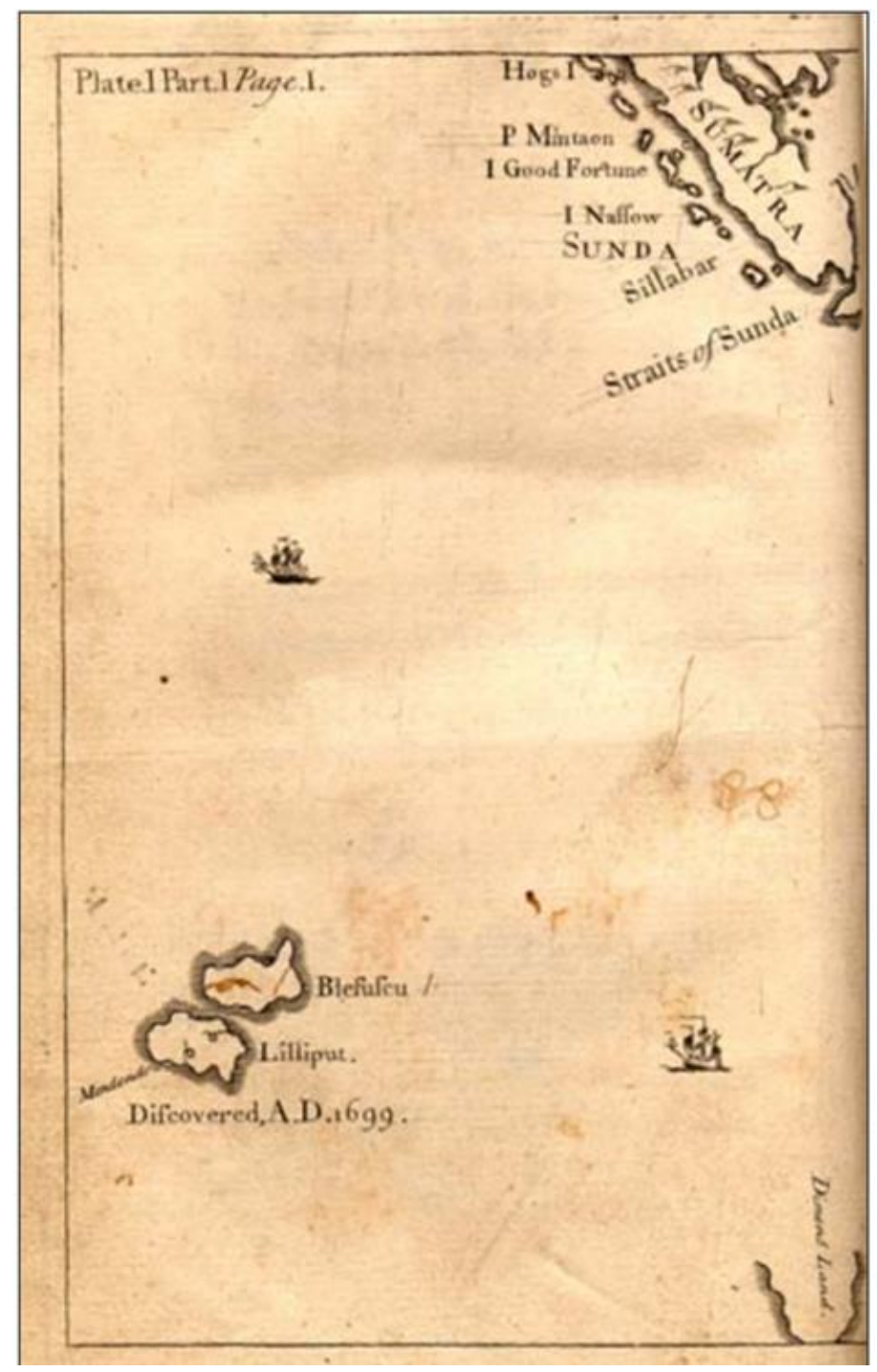

Original map, Pt I, Gulliver's Travels, 1726. Creator Herman Moll (cartographer). Open domain.

Susan Stewart writes that the Lilliputians, like the earlier figure of Tom Thumb, are always depicted amidst things that establish scale. For example, in Tom Thumb, the story of a diminutive boy born to a regular-sized couple, Tom's father's sigh becomes a cyclone, an acorn a cradle. Descriptions of the miniature world foreground context, 
eTropic 20.2 (2021) Special Issue: Tropical Imaginaries and Climate Crisis

and in so doing, slow down the narrative action. When we confront the miniature, "description and depiction" assume the dominant roles. As the reader is immersed in contextual information, space and time are compressed into an instance. The sensory dimensions of the miniature object, its "tactile and olfactory" traits, are reduced to visual depiction, and time essentially freezes. Stewart continues:

The miniature offers a world clearly limited in space but frozen and thereby both particularized and generalized in time-particularized in that the miniature concentrates upon the single instance and not upon the abstract rule, but generalized in that that instance comes to transcend, to stand for, a spectrum of other instances. (1996, p. 48)

Stewart finds a correspondence between the miniature worlds of fiction and material culture in that the cessation of narrative time through contextualization finds an analogue in engagement with diminutive objects - such as dollhouse interiors. By eclipsing the everyday world, playing with the dollhouse magnifies interiority; reality becomes "anterior and exterior" to the shrunken rooms and furnishings. Furthermore, in the tiny world, time is compressed to scale, and a duration of, say, five minutes in the "real" world may translate to thirty minutes in the tiny one. "Miniature time," she writes, excludes and defers social experience. Its hyper-focus on the visual enables time to transcend "the duration of everyday life in such a way as to create an interior temporality of the subject" (Stewart, 1996, p. 66).

In contrast, fictional giants represent for Stewart the "physical world of disorder and disproportion" (Stewart, 1996, p. 74). In Gulliver's Travels, the island of Brobdingnag presents new challenges for Gulliver as the gigantic envelops him. The narrative emphasis is on the giant's movement and its destructive consequences (Stewart, 1996, p. 86).

Our impulse is to create an environment for the miniature, but such an environment is impossible for the gigantic: instead the gigantic becomes our environment, swallowing us as nature or history swallows us. (Stewart, 1996, p. 89)

It is tempting to imagine the author Jonathan Swift reading earlier accounts of Madagascar as inspiration for Gulliver's Indian Ocean travels. In 1658, Etienne de Flacourt published his Histoire de la Grande Isle Madagascar. Flacourt, named Governor of Madagascar by the French East India Company in 1648, is reputed to be one of the few Europeans to have recorded seeing the island's giant elephant bird, Aepynornis maxiumus, soon before it was killed off by hunting. The bird features in H.G. Wells' short story, Aepyornis Island, published in 1894, in which an English 
collector named Butcher travels to Madagascar to find rarities for a buyer in London. He finds several eggs of the long extinct Aepyornis maximus (Figure 2). To his shock, one hatches and matures, and Butcher finds himself pitched into a life and death battle with the resurrected giant. It seems an instinctive shot at retribution by a species extirpated by humankind (Wells, 1894; Sodikoff, 2013).

Figure 2. Aepyornis skeleton. Quaternary of Madagascar by Monnier, 1913.

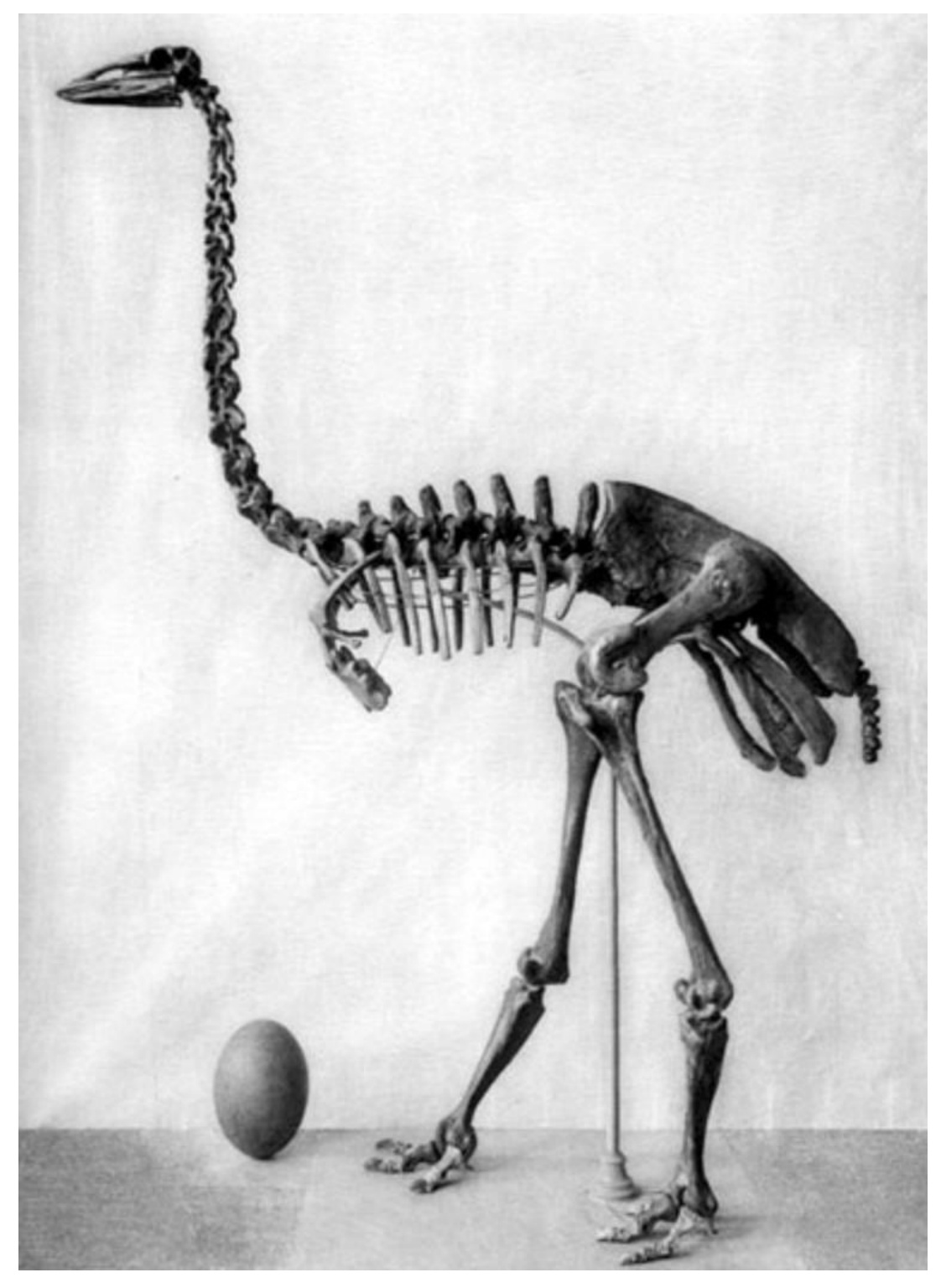

Source: Wikipedia public domain

In his History of the Great Island, Flacourt explains that Malagasy people wanted him to believe that giant and pygmy people used to roam the island. But after having researched the matter, he learned that these were mere fables (Dubois, 1926, p. 105). The subject of the pygmies prompted speculation among European natural scientists, 
eTropic 20.2 (2021) Special Issue: Tropical Imaginaries and Climate Crisis

not satisfied with Flacourt's conclusion, about whether or not these societies did exist. Among the believers was Philibert Commerson who undertook botanical explorations in Mauritius and Madagascar. After a voyage to Madagascar in 1769, he wrote a letter to his friend, astronomer Lalande, in which he contradicts Flacourt's claim that the pygmies were a mythical race. He claims to have witnessed the people firsthand (Morel, 2012).

The sensational contents of Commerson's letter were translated into English in a 1791 issue of The Literary Magazine and British Review. Commerson describes the diminutive people, known as the Quimos (or Kimos or Kimosy), whose smallness pushed them upslope into the high mountains as a means of self-protection from neighboring marauders. He writes that "Flacourt calls these dwarfish people pigmies, and mixes their history with that of a pretended race of giants, who, as the ancient tradition of Madagascar assures us, made formerly very great ravage in the island" (Commerson, 1791, p. 45). While Commerson agrees that the giants were mythical, he insists that the Kimos are real and proceeds to detail their appearance, geographical location (in the southern central highlands), livelihood practices, and social relationships with surrounding groups. Despite an attempt to sound scientific, his descriptions strain credulity:

The distinguishing characteristics of these small people are, that they are whiter or at least paler in colour, than all the negroes hitherto known; that their arms are so long, that they can stretch their hands below their knees without stooping; and that the women have scarcely any breasts, except when they suckle, and even then, we are assured, the greater part of them are obliged to make use of cow's milk, in order to nourish their young (Commerson, 1791, p. 43).

Commerson was assured that the Kimos women do not menstruate, but rather "at those periods when other women are subject to this evacuation, the skin of their body becomes of a blood-red colour" (1791, p. 46). He later adds that he had "procured a Kimos woman" from a province chief in Mandrary:

This woman is rather of a tall stature, considering the general measure allowed to the females of her nation, yet her height does not exceed three feet seven inches. She is between thirty and thirty-two years of age; her arms are very long, her hands have a great resemblance to the paws of an ape, and her bosom is as flat as that of the leanest man, without the least appearance of breasts. (Commerson, 1791, p. 46-47). 
eTropic 20.2 (2021) Special Issue: Tropical Imaginaries and Climate Crisis

Subsequently, scholars concluded that Commerson had actually purchased a woman with achondroplasia, or dwarfism.

The early fascination with pygmy humans in Madagascar continued into the nineteenth century, when another account of the Kimos by Andre Coppalle, portrait painter of Malagasy King Radama, asserted their existence based on his conversations with Europeans there. By the nineteenth and early twentieth centuries, numerous European and Malagasy scholars were collecting testimonies of elderly individuals who had witnessed pygmy people, since the so-called Kimos and various branches of this population had ostensibly vanished. Their elusive history blends into that of the Vazimba, a putative indigenous population of relatively small people whose origins have been much debated (Dubois, 1926, pp. 115-119). Tales of small humanoids persist in Madagascar, and in 2000 in the northeast region of Mananara-Nord, I was told of the kalañoro, a community of long-haired, fanged dwarfs that once inhabited the forest but died out as the forest disappeared and now exist as a type of spirit. Kalañoro stories are told all over the island, but scholars have never considered them factual. In contrast, generations of scholars aimed to substantiate the Kimos myth through the collection of oral histories. This methodology has also been used to investigate several faunal species presented in Flacourt's book. Presumed to have become extinct after Flacourt published his findings, certain species mysteriously survived in Malagasy oral tradition until the twentieth century.

American paleobiologist David Burney and Malagasy archaeologist Ramilisonina (1998) carried out ethnographic research with elders in a western coastal village in 1995. They collected accounts of an animal called kilopilopitsofy ("floppy ears"). One had been sighted as late as 1976, lending oral evidence of the possibility of a sole survivor pygmy hippopotamus at that time. They also collected an eye-witness account of a large lemur species, called kidoky, which was spotted around 1952 and compared in size to a seven-year-old child. First-hand witnesses and their testimonies of cryptic extinct megafauna appear to have also vanished.

While it is often assumed that humans rapidly overhunted the island's giant species, as well as the pygmy hippo, a recent discovery challenges this view. In 2020 , fossilized bones of the giant sloth lemur were found in a cave alongside a painting on the cave wall depicting this species, believed to have disappeared around 1000 years ago (Davis, 2020). The findings suggest the possibility of a giant species overlapping with humans for a longer stretch of time than previously thought.

The knowledge contained in Malagasy people's accounts of last survivors is both ethnographically valuable for its own sake and has the potential to advance science by fleshing out the timelines and localities of faunal extinctions. Following earlier 
eTropic 20.2 (2021) Special Issue: Tropical Imaginaries and Climate Crisis

ethnographers, historians, and biologists seeking out evidence of wondrous animals and societies, Burney and Ramilisonina successfully unearthed tantalizing clues about dwarf and giant species hidden in clandestine niches and, eventually, human memory.

\section{‘Cryptic' Kinds}

Tales of strange animals have long compelled researchers in Madagascar to sift evidence from oral tradition and to differentiate cryptozoological from cryptic species. The latter term, germane for actually-existing minifauna, has several meanings.

One entry for "cryptic" in the Oxford English Dictionary, and the meaning of its most common usage, is "something enigmatic or hidden; a secret, a mystery", reminding us of cryptic clues. As we move into Zoology, the word primarily denotes camouflage: "Of markings, coloration, behaviour, etc.: serving for or giving concealment or camouflage; (of an animal) exhibiting such coloration or behaviour." And in Biology, the meaning becomes more technical: "Of a property, form, etc.: present but not manifest or readily detectable; (of species) morphologically similar but unable to hybridize or interbreed; (of a gene) present but not normally expressed. Also: relating to or characterized by such a property, form, etc." (Oxford English Dictionary).

As mentioned above, Europeans' written accounts of unusual species and dwarf and giant societies had lured foreign explorers to Madagascar's shores since the seventeenth century. The accounts were cryptic insofar as they left clues to the probable whereabouts of these elusive societies, but explorers' quests were frustrated by the blur of fact and fable. Ultimately, the Kimos proved to be cryptozoological, a mythical society given undue scientific validity for a while, much as a species of wild dog known as the kelibetratra ("little big chest") is believed by many people, including a couple of doctors I met, to be the reservoir of canine rabies. Yet the species does not exist.

The zoological and biological meanings of "cryptic" aptly describe the qualities of recently discovered vertebrate dwarf species - for instance, the sizes of miniature frogs, chameleons, and lemurs, as well as their coloration, makes them difficult for the human eye to see. Outwardly indistinguishable dwarf species that are taxonomically separated via technology comprise the third category of "cryptic." Although the mode of discovery marks an historical turning point, the general public viewership has no way to perceive in an image whether a species is wild-caught or lab-unveiled. Increasingly, the two modes of discovery go hand-in-hand. Yet the technologyassisted boom in species discovery shapes contemporary "mass extinction" discourse by counterbalancing the perception of cataclysmic loss. We are pulled inward, celebrating signs of renewal emerging from miniscule contexts. 
eTropic 20.2 (2021) Special Issue: Tropical Imaginaries and Climate Crisis

Earlier iterations of extinction discourse deemed the loss of indigenous lifeways and endemic species a sad but necessary casualty of technological progress. However, by the 1960s, the problem of extinction acquired the status of crisis. Marit Ruge Bjærke writes that

the new idea of an ongoing mass extinction showed the problem of species extinctions to be even more dramatic than before. The sixth extinction was of a global nature, both when considered in space and in time. (Bjærke, 2011, p. 130)

"Mass extinction" is defined as a phenomenon where extinction rates exceed speciation rates to the point where over seventy-five percent of species die out within two million years or less (a brief interval, geologically-speaking) (Barnosky et al., 2011). Within this desolate context, species discoveries represent hopeful events that offset the immensity of the ecological threat. Representations of newly found miniature species help to minimize the void of life by reducing the scale of our focus. This magnification of the tiny has the potential to slow down the perceived tempo of species loss and to temporarily blot out the anterior reality of habitat loss and global warming.

A few examples of the two intertwined modes of species discovery follow. One mode refers to the discovery of cryptic minifauna that are wild-caught, "out in the world," a difficult feat given their tininess or camouflage. The other mode refers to species discovered "in the lab," where Linnean taxonomic methods are ceding way to DNA analysis and electron scanning, particularly useful for microscopic and miniature fauna.

The first example is the discovery of two new species of mouse lemur in 2005 by a team of German and Malagasy scientists. They named one after renowned field biologist Steve Goodman (Figure 3). The lemur's scientific name is Microcebus lehilahytsara - "lehilahytsara" is Malagasy for "good man." The discovery was not at the moment of species capture, but in the "unexpected revelation" of the new species through DNA comparison (BBC News, 2015; Mongabay, 2005). 
eTropic 20.2 (2021) Special Issue: Tropical Imaginaries and Climate Crisis

Figure 3. Goodman's mouse lemur (Microcebus lehilahytsara).

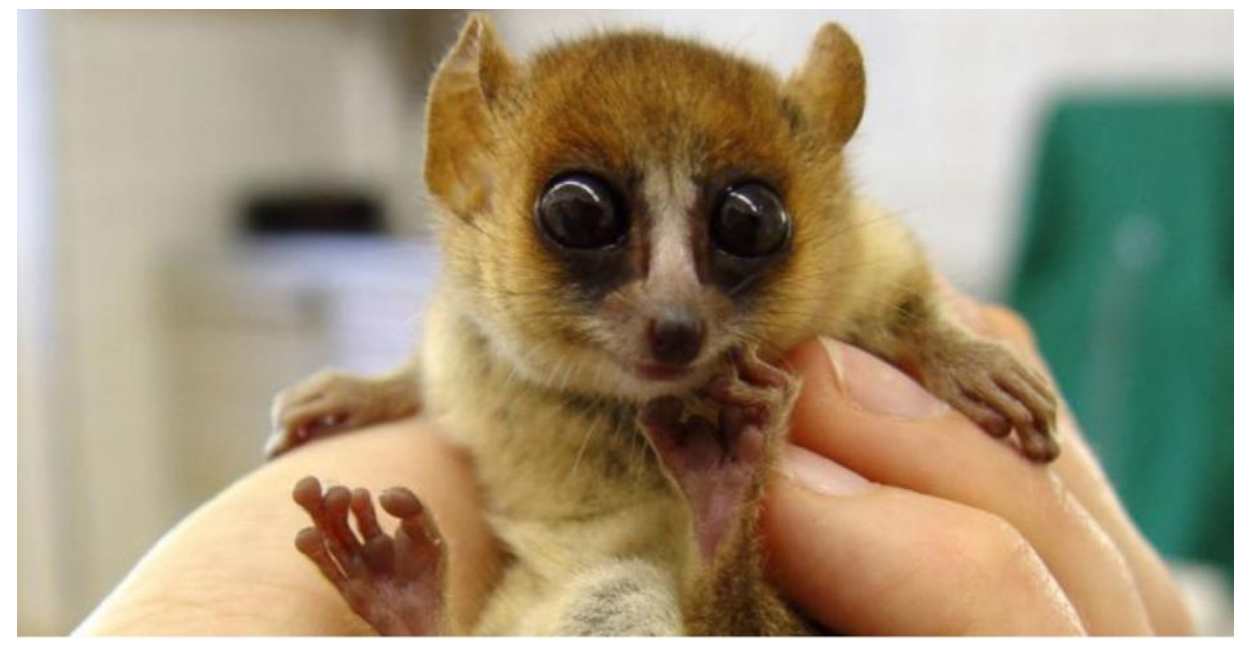

Source: https://www.eurekalert.org/news-releases/741671. Photograph by Robert Zingg.

Second, in March 2019, Mark Scherz, an evolutionary biologist at the University of Potsdam, published a study describing several "astronomically small" species of frog, given the genus name Mini. The species were Mini mum, Mini ature, and Mini scule (Donahue, 2019, p. 1). The author of the National Geographic article, Michelle Donahue, draws on metaphors of scale that invoke the drab surroundings of a modern office. The smallest of these micro-frogs, Mini mum, is the size of a "standard staple," she writes, and the largest, the length of a "microSD card" (Figure 4). All the cryptic Minis were discovered in leaf litter and grasses of Madagascar's eastern forests, but their unique species identities were not revealed until the scientists analyzed snippets of their DNA and used microtomography (high definition 3-D scanning) to discern structural differences from other species.

Figure 4. Mini mum gen. et sp. nov. in life and its habitat in Manombo Special Reserve.

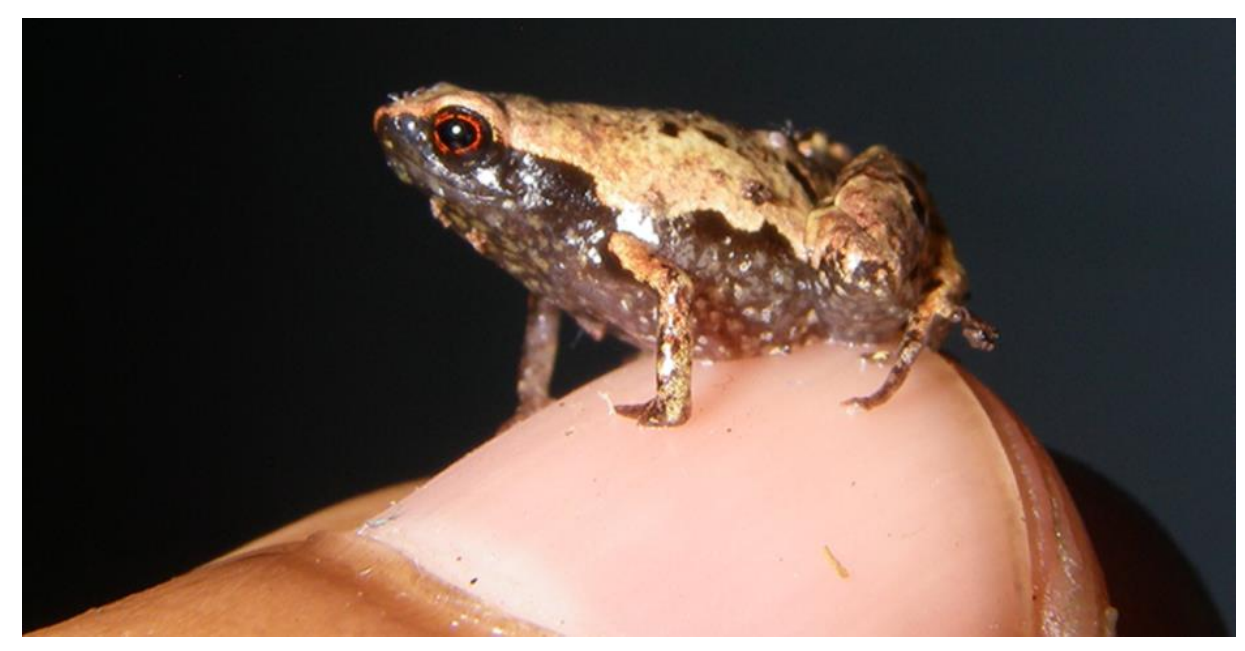

Source: Scherz et al., 2019.

eTropic: electronic journal of studies in the tropics 
Third, in February 2021, a Malagasy and German expedition team discovered a male and a female Brookesia nana, a previously unknown subspecies of chameleon. Two mitochondrial gene fragments were analyzed to compare to other Brookesia species. Most miniature chameleons in Madagascar inhabit very small ranges, predominantly in two locations in the north. Their limited ranges and tiny sizes mean that they are notoriously difficult to find, as well as to differentiate from similar species, which explains why they had largely been overlooked until now. The scientists involved note that the forest habitat at lower elevations had been "completely eradicated" and cattle husbandry and swidden agriculture were eroding the forest at higher altitudes, including the type locality of $B$. nana (Glaw et al., 2021; Meiri et al., 2018).

A reporter likened the size of Brookesia nana to a "sunflower seed," making them slightly smaller than Brookesia micra (Figure 5) discovered in Madagascar in 2012 (Guardian, 2021). The comparison of chameleon to seed suggests its generative potential, a new life emerging from the depleted soil. The miniature chameleons have also been genetically analysed.

Figure 5. Brookesia micra sp. n. from Nosy Hara, northern Madagascar. Juvenile on fingertip.

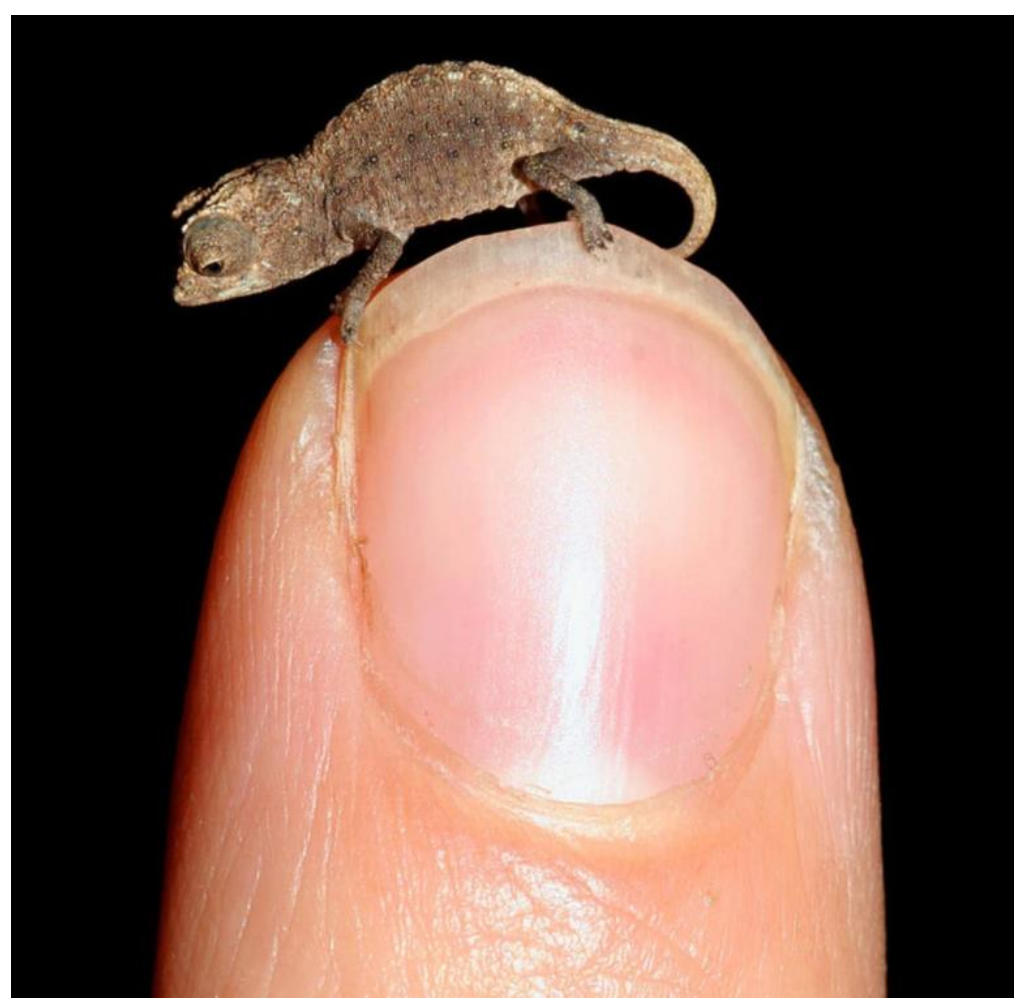

Source: Glaw et al., 2012. 
eTropic 20.2 (2021) Special Issue: Tropical Imaginaries and Climate Crisis

Species discoveries that rely on the decryption of DNA and microtomography help reshape phylogenies and systematics. In contrast to the earlier days when discovery involved capturing wild animals and applying Linnean taxonomic method to name them, DNA barcoding resolves human fallibility. A short DNA sequence is read from a genetic sample and recorded in a public database, which allows for its comparison against all available genetic samples.

The technology has effected a change in scientists' ecological perspective from "species-based" to "gene-based." Stefan Caddy-Ratalic and Andrew Lowe explain that this shift more accurately reflects the genetic fluidity of ecosystems. DNA analysis, as well as the use of a scanning transmission electron microscopy (STEM) that yields three-dimensional renderings of small species' structures, offer more "objective" data compared to the taxonomic opinions of individual scientists (Caddy-Retalic \& Lowe, 2012; van den Bos et al., 2018). Thanks to these technologies, micro- and mini-fauna are proliferating, despite the erosion, destruction, and warming of their natural habitats. By downscaling the adventure of species-hunting to the atomic level, DNA analysis and microtomography have opened up new exploratory terrains and opportunities for scientists. New technology enables us to see novel life that would otherwise remain inaccessible, much as the "greenhouse effect" appears to us now an unobservable fact "characterised by "nonlocality" and apprehended through the "numbers, graphs, or texts by which climate change becomes a defined object" (Kverndokk \& Eriksen, 2021, p. 6). Miniature species are contextualized in a forest of genomes. Humanity, as well as the liveliness of the animal, recede from the frame along with the moral self-reflection that such framing demands.

I have suggested that online images of recently discovered miniature species compel us to imagine not only our individual histories but also the evolutionary and ethnological histories of particular terrains. For Westerners, the framing of a miniature animal on a human digit also conveys a history of our species. The clipped or jagged nail, the scruffy or manicured cuticle of the (usually) White finger, encapsulate impactful histories of European enchantment with insular and cryptic wildlife. While the fingers may impart gentleness, the photographs of scale also implicate human handiwork in mass extinction and climate change. They nurture the impulse to take refuge in the slowed-down time and fertile world of the miniature, while out here at human scale, the dregs of our history have become an all-consuming environment. 
eTropic 20.2 (2021) Special Issue: Tropical Imaginaries and Climate Crisis

\section{References}

Barnett, B. (1937). Kangaroos and Chameleons. The Field, February 27, 470.

Barnosky, A.D., Matzke, N., Tomiya, S., Wogan, G.O.U., Swartz, B., Quental, T.B., Marshall, C., McGuire, J.L., Lindsey, E.L., Maguire, K.C., Mersey, B., \& Ferrer, E.A. (2011). Has the Earth's Sixth Mass Extinction Already Arrived? Nature 471, 51-57. https://doi.org/10.1038/nature09678

BBC News. (2005). New Lemurs Found in Madagascar. Tuesday, 9 August, http://news.bbc.co.uk/2/hi/science/nature/4135670.stm

Brantlinger, P. (2003). Dark Vanishings: Discourse on the Extinction of Primitive Races, 1800-1930. Cornell University Press.

Burney, D. A. (1997). Tropical Islands as Paleoecological Laboratories: Gauging the Consequences of Human Arrival. Human Ecology 25(3), 437-457. https://doi.org/10.1023/A:1021823610090

Burney, D. A. \& Ramilisonina. (1998). The Kilopilopitsofy, Kidoky, and Bokyboky: Accounts of Strange Animals from Belo-sur-mer, Madagascar, and the Megafaunal 'Extinction Window.' American Anthropologist, 100(4), 957-966. https://doi.org/10.1525/aa.1998.100.4.957

Bjærke, M.R. (2021). The sixth extinction: Naming time in a new way. In Kverndokk, K. Bjærke, M.R. \& Eriksen, A. (Eds.). Climate Change Temporalities: Explorations in Vernacular, Popular, and Scientific Discourse (pp. 125-140). Routledge. https://doi.org/10.4324/9781003037415-12

Caddy-Retalic, S. \& Lowe, A. (2012). DNA barcoding: a better way to discover species. The Conversation, March 4. https://theconversation.com/dna-barcoding-a-better-way-todiscover-species-4933

Cahill, A.E., Aiello-Lammens, M.E., Fisher-Reid, M.C., Hua, X., Karanewsky, C.J., Ryu, H.Y., Sbeglia, G.C., Spagnola, F., Waldron, J.B., Warsi, O., \& Wiens, J.J. (2013). How does climate change cause extinction? Proceedings of the Royal Society $B$ : Biological Sciences 280: 20121890. https://doi.org/10.1098/rspb.2012.1890

Carlquist, S. (1974). Island Biology. Columbia University Press. https://doi.org/10.5962/bhl.title.63768

Commerson, P. (1791). Account of the Quimos, a race of Pigmies, found in the island of Madagascar. The Literary Magazine and British Review 7: 43-47.

Davis, J. (2020). Only known drawing of extinct giant sloth lemur found in cave." Natural History Museum, Science News, June 28, https://www.nhm.ac.uk/discover/news/2020/june/only-known-drawing-of-extinct-giantsloth-lemur-found-in-cave.html

DelPero, M. (2014). The Red Island and the Seven Dwarfs: Body Size Reduction in Cheirogaleidae. Journal of Biogeography, 41(10), 1833-1847. https://doi.org/10.1111/jbi.12327

Donahue, M. Z. (2019). New staple-size frog is one of the tiniest ever discovered. National Geographic, March 27.

Dubois, R.P.H.M. (1926). Les origines des Malgaches. Anthropos 21 (1/2), 72-126. Published by: Nomos Verlagsgesellschaft.

Dunham, A.E., Erhart M.E., \& Wright, P.C. (2011). Global climate cycles and cyclones: consequences for rainfall patterns and lemur reproduction in southeastern Madagascar. Global Change Biology 17, 219-227. https://doi: 10.1111/j.13652486.2010.02205.x

Flacourt, E. de (1661). Histoire de la Grande Ile Madagascar. Paris: Nicolas Oudot. Digital publication: https://gallica.bnf.fr/ark:/12148/bpt6k1047463.image.f2. 
eTropic 20.2 (2021) Special Issue: Tropical Imaginaries and Climate Crisis

Forsberg, L. (2015). Nature's Invisibilia: The Victorian microscope and the miniature fairy. Victorian Studies 57(4): 638-666. https://doi.org/10.2979/victorianstudies.57.4.03

Foster, J.B. (1964). "Evolution of mammals on islands." Nature, 202, 234-235. https://doi.org/10.1038/202234a0

Glaw, F., Köhler, J., Townsend, T.M., Vences, M. (2012). Rivaling the World's Smallest Reptiles: Discovery of miniaturized and microendemic new species of leaf chameleons (Brookesia) from Northern Madagascar. PLoS ONE 7(2): e31314. https://doi.org/10.1371/journal.pone.0031314

Glaw, F., Köhler, J., Hawlitschek, O., Ratsoavina, F.M., Rakotoarison, AA., Scherz, M. \& Vences, M. (2021). Extreme miniaturization of a new amniote vertebrate and insights into the evolution of genital size in chameleons. Scientific Reports 11, (2522), https://doi.org/10.1038/s41598-020-80955-1

Greenfield, P. (2020). Counting the Species: How DNA barcoding is rewriting the Book of Life. The Guardian, October 7.

https://www.theguardian.com/environment/2020/oct/07/counting-the-species-howdna-barcoding-is-rewriting-the-book-of-life-aoe

Guardian, The. (2021). Seed-sized chameleon found in Madagascar may be world's tiniest reptile. February 5. https://www.theguardian.com/environment/2021/feb/05/seedsized-chameleon-madagascar-world-tiniest-reptile.

Hannah, L., Dave, R., Lowry, P. P., Andelman, S., Andrianarisata, M., Andriamaro, L., Cameron, A., Hijmans, R., Kremen, C., Mackinnon, J., Randrianasolo, H. H., Andriambololonera, S., Razafimpahanana, A., Randriamahazo, H., Randrianarisoa, J., Razafinjatovo, P., Raxworthy, C., Schatz, G. E., Tadross, M., \& Wilmé, L. (2008). Climate change adaptation for conservation in Madagascar. Biology letters, 4(5), 590-594. https://doi.org/10.1098/rsbl.2008.0270

Kverndokk, K. \& Eriksen, A. (2021.) Climate change temporalities Narratives, genres, and tropes. In Kverndokk, K. Bjærke, M.R. \& Eriksen, A. (Eds.). Climate Change Temporalities: Explorations in Vernacular, Popular, and Scientific Discourse (pp. 314). Routledge https://doi.org/10.4324/9781003037415

Landecker, H. (2016). Antibiotic Resistance and the Biology of History. Body \& Society, 22(4), 19-52. https://doi.org/10.1177/1357034X14561341

Lanting, F. (1990). Madagascar: World Out of Time. Photographs by Frans Lanting. Introduction by Gerald Durrell; Essays by Allison Jolly and John Mack. The University of Michigan. Aperture; First Edition.

Lomolino, M. V. (2005). Body size evolution in insular vertebrates: generality of the island rule. Journal of Biogeography, 32, 1683-1699.

Lomolino, M. V., Vaan der Greer, A. A., Lyras, G. A.; Palombo, M. R., Sax, D.F., \& Rozzi, R. (2013). Of mice and mammoths: Generality and antiquity of the island rule. Journal of Biogeography, 40(8), 1427-1439. https://doi.org/10.1111/ibi.12096

Lorimer, Ja. 2015: Wildlife in the Anthropocene: Conservation After Nature. University of Minnesota Press. https://doi.org/10.5749/minnesota/9780816681075.001.0001

Meiri, S., Bauer, A.M., Allison, A., Castro-Herrera, F., Chirio, L., Colli, G., Das, I., Doan, T., Glaw, F., Grismer, L.L., Hoogmoed, M., Kraus, F., LeBreton, M., Meirte, D., Nagy, Z.T., Noguiera, C.C., Oliver, P., Pauwels, O.S.G., Pincheira-Donoso, D., Shea, G., Sindaco, R., Tallowin, O.J.S., Torres-Carvajal, O., Trape, J-F., Uetz, P., Wagner, P., Wang, Y., Ziegler, T., \& Roll, U. (2018). Extinct, obscure or imaginary: The lizard species with the smallest ranges. Diversity and Distributions, 24, 262-273. https://doi.org/10.1111/ddi.12678

Mercier, J-L, \& Wilmé, L. (2013). The Eco-Geo-Clim model: Explaining Madagascar's endemism. Madagascar Conservation \& Development, 8(2), 63-68.

https://doi.org/10.4314/mcd.v8i2.3 
eTropic 20.2 (2021) Special Issue: Tropical Imaginaries and Climate Crisis

Mongabay. (2005). Two tiny lemur species discovered in Madagascar. August 9. https://news.mongabay.com/2005/08/two-tiny-lemur-species-discovered-inmadagascar/

Morel, J-P. (2012). Philibert Commerson à Madagascar et à Bourbon." Copie sur pierrepoivre.fr, décembre 2012, $16 \mathrm{pp}$.

Oxford English Dictionary. https://www-oedcom.proxy.libraries.rutgers.edu/view/Entry/45358? redirectedFrom=cryptic\#eid

Raxworthy, C.J, Pearson, R.G, Rabibisoa, N., Rakotondrazafy, A.M, Ramanamanjato, J-B., Raselimanana, A.P., Wu, S., Nussbaum, R.A., \& Stone, D.A. (2008). Extinction vulnerability of tropical montane endemism from warming and upslope displacement: a preliminary appraisal for the highest massif in Madagascar. Global Change Biology, 14 (8), 1703-1720. https://doi.org/10.1111/j.1365-2486.2008.01596.x

Scherz, M.D., Hutter, C.R., Rakotoarison, A., Riemann, J.C., Rödel, M-O, Ndriantsoa, S.H., et al. (2019). Morphological and ecological convergence at the lower size limit for vertebrates highlighted by five new miniaturised microhylid frog species from three different Madagascan genera. PLoS ONE 14(3): e0213314. https://doi.org/10.1371/journal.pone.0213314

Sodikoff, G.M. (2013). The Time of Living Dead Species: Extinction Debt and Futurity in Madagascar. In P. Y. Paik \& M. Wiesner-Hanks (Eds.) Debt: Ethics, the Environment, and the Economy (pp. 140-163). 21st Century Studies Series. Indiana University Press.

Stewart, S. (1993). On Longing: Narratives of the Miniature, the Gigantic, the Souvenir, the Collection. Duke University Press. https://doi.org/10.1215/9780822378563

Swift, J. (1920 [1726]). Gulliver's Travels. Edited with an Introduction by Ernest Bernbaum. Harcourt, Brace and Company.

Tadross, M., Randriamarolaza, L., Rabefitia, Z. \& Zheng, K. Y. (2008). Climate change in Madagascar; recent past and future, pp. 18. Washington, DC: World Bank.

Transforming the World. (n.d.). The Island Rule: How Insular Populations Become Dwarfs and Giants. Digital publication. http://whitenies.blogspot.com/2015/10/the-island-rulehow-insular-populations.html. Accessed June 10, 2021.

Van den Bos, K.H.W., Altantzis, T., De Backer, A., Van Aert, S., \& Bals, S. (2018). Recent breakthroughs in scanning transmission electron microscopy of small species. Advances in Physics: $X,(3) 1,815-833$. https://doi.org/10.1080/23746149.2018.1480420

Vieilledent, G., Gardi, O., Grinand, C., Burren, C., Andriamanjato, M., Camara, C., Gardner, C.J., Glass, L., Andriambolantsoa, R., Ratsimba, H.R., Gond, V., \& Rakotoarijaona, J-R. (2016). Bioclimatic envelope models predict a decrease in tropical forest carbon stocks with climate change in Madagascar. Journal of Ecology, 104, 703-715. https://doi.org/10.1111/1365-2745.12548

Wright P.C. (2006). Considering climate change effects in lemur ecology and conservation. In Gould, L. \& Sauther, M.L. (Eds.) Lemurs: Ecology and Adaptation, pp. 387-404. Springer. https://doi.org/10.1007/978-0-387-34586-4 18 


\section{Acknowledgments}

An earlier version of this paper was presented at the 2021 meetings of the Association of Social Anthropologists for a plenary panel on Extinction chaired by Daniel Knight and Richard Irvine of the University of St Andrews. I am grateful to them, to copanelists Dace Dzenovska and Liana Chua, to Christos Lynteris, and to all those who joined the fascinating discussion. I also thank Michael Hathaway and the anonymous reviewers for their helpful input. Finally, I am grateful to Anita Lundberg for her thoughtful suggestions and editing.

Dr Genese Marie Sodikoff is Associate Professor of Anthropology at Rutgers University-Newark. Since 1994, her research has examined Madagascar's political ecology, including the labor relations of biodiversity conservation, cultural and biotic extinction events, and the cultural life of zoonoses. Her recent work, supported by a Mellon New Directions Fellowship, is tentatively called "Dwelling with Plague: House, Tomb, and Reservoir in Madagascar." It explores the impacts of endemic bubonic plague on Malagasy kinship and funerary practices. She is the author of Forest and Labor in Madagascar: From Colonial Concession to Global Biosphere and the editor of The Anthropology of Extinction: Essays on Culture and Species Death. 